\title{
PIRKUMA LĪGUMA OBJEKTA IZPRATNE JAUNO PATĒRĒTĀJU PIRKUMA DIREKTĪVU GAISMĀ
}

\section{UNDERSTANDING THE OBJECT OF PURCHASE AGREEMENT IN THE LIGHT OF THE NEW CONSUMER SALES DIRECTIVES}

\author{
Jānis Kārklinšs, Dr. iur. \\ Latvijas Universitātes Juridiskās fakultātes \\ Civiltiesisko zinātnu katedras profesors
}

\begin{abstract}
Summary
One of the objectives of the European Union is to create an internal market in which the free movement of goods and services is ensured. At the same time, by ensuring the free movement of goods and services, the European Union has a duty to promote a high level of consumer protection. In order to achieve both of these goals at the same time, the European Union has adopted, among other things, a significant number of directives, which the Latvian legislator has mostly transposed into the Consumer Rights Protection Law. Nevertheless, the development of digital technologies has made it necessary to lay down special rules in the event that the subject of the contract contains digital elements.

Taking into account the above, this article provides analysis of the content of the new consumer sales directives $(2019 / 770,2019 / 771)$, their implementation as much as possible in connection with the existing Latvian legal system, as well as views some legal issues related to the implementation of directives in Latvia.
\end{abstract}

Atslēgvārdi: jaunā patērētāju pirkuma direktīva, digitāls pakalpojums, digitāls elements, digitāls saturs, preces ar digitālu elementu.

Keywords: consumer sales directive, digital services, digital elements, digital content, goods with digital elements.

\section{Ievads}

Viens no Eiropas Savienības darbības mērķiem ir izveidot iekšējo tirgu, kurā ir nodrošināta preču un pakalpojumu brīva aprite. Savukārt, nodrošinot preču un pakalpojumu brīvu apriti, Eiropas Savienībai ir pienākums veicināt augsta patērētāju aizsardzības līmeņa sasniegšanu. Lai vienlaikus īstenotu abus šos mērḳus, Eiropas Savienība ir pieñēmusi tostarp ievērojamu skaitu direktīvu, kuras Latvijas likumdevējs lielākoties ir pārṇēmis Patērētāju tiesību aizsardzības likumā. Neskatoties uz minēto, digitālo tehnoloǵu attīstības rezultātā ir radusies nepieciešamìba paredzēt īpašus noteikumus gadījumā, ja līguma objekts satur digitālus elementus. 
Tādēḷ vairāk nekā pirms pusotra gada - 2019. gada 20. maijā - Eiropas Parlaments un Padome pieṇēma divas direktīvas - Direktīvu 2019/770 par dažiem digitālā satura un digitālo pakalpojumu piegādes līgumu aspektiem ${ }^{1}$ un Direktīvu 2019/771 par atsevišķiem preču pārdošanas līgumu aspektiem² (turpmāk kopā Direktivvas). Šìs Direktīvas Eiropas Savienības dalībvalstīs paplašinās un precizēs patērētājam piešḳirtās tiesības, vienlaikus harmonizējot līgumus, ar kuriem digitāls saturs, digitāls pakalpojums vai arī prece ar digitāliem elementiem tiek atsavināta.

Par pirmsākumu šo Direktīvu izstrādāšanai varētu minēt "Eiropas Savienības Digitālā vienotā tirgus stratēgiju” jeb Eiropas Komisijas 2015. gada 6. maija paziņojumu Eiropas Parlamentam, Padomei, Eiropas Ekonomikas un sociālo lietu komitejai un Eiropas Reǵionu komitejai. Šajā paziņojumā Komisija vērsa uzmanību tostarp uz tiesiskā regulējuma trūkumu digitālajam saturam un precēm ar digitāliem elementiem, norādot, ka attiecībā uz tiesiskās aizsardzības līdzekḷiem par tiešsaistē iegādātām precēm, kuru digitālais saturs ir bojāts, speciāli noteikumi Eiropas Savienībā nepastāv vispār un tikai daži valstu nacionālie noteikumi reglamentē šādus gadijjumus. ${ }^{3}$ Šāda pieeja nav efektīva, jo atšksirīgie 27 dalībvalstu patērētāju tiesību aizsardzības un līgumtiesību noteikumi attur uzṇēmumus no pārrobežu tirdzniecības un liedz patērētājiem gūt labumu no konkurētspējīgākajiem piedāvājumiem un no plašā tiešsaistes piedāvājuma spektra. ${ }^{4}$

Kā uz to norādijis pats Eiropas Savienības likumdevējs, izmaiṇas Eiropas Savienības dalībvalstu regulējumā ir nepieciešamas tostarp, lai radītu vienotu digitālu tirgu Eiropas Savienībā, kas savukārt tādējādi veicinātu Eiropas Savienības dalībvalstu spēju konkurēt globālajā digitālajā tirgū un sekmētu e-komercijas attīstību kopumā (Direktīvu 1. un 3. apsvērums). Šāds mērḳis ir saprātīgs, ņemot vērā šobrīd tirgū pastāvošās tendences, t. i., e-komercijas sektora straujo attīstību, to, ka 2020. gadā ar e-komercijas starpniecību komersanti pārdeva preces par kopēju apmēru teju 4 triljonu Amerikas Savienoto Valstu dolāru vērtībā, ${ }^{5}$ kā arī to, ka Eiropas Savienības dalībvalstu izaugsme digitālajā tirgū šobrīd ir viena no lēnākajām pasaulē. ${ }^{6}$

Abu iepriekš minēto Direktīvu transponēšanas termiņš ir sakritīgs, t. i., Eiropas Savienības dalībvalstīm nepieciešamie grozijumi jāpieṇem un jāizsludina līdz 2021. gada 1. jūlijam, savukārt šiem grozījumiem jāstājas spēkā līdz ar 2022. gada 1. janvārim. Raugoties uz Eiropas Savienības dalībvalstu regulējumu šobrīd, kā arī tiesību zinātnieku paustajām atziṇām šajās valstīs, nākas secināt, ka arī citas dalībvalstis vēl tikai tiecas izstrādāt regulējumu, ar kuru Direktīvu normas būtu iestrādātas dalībvalstu tiesību sistēmās. Kā tas tiks norādīts tālāk, domājams, ka

1 Eiropas Parlamenta un Padomes Direktīva 2019/770 par dažiem digitālā satura un digitālo pakalpojumu piegādes līgumu aspektiem. Pieņemta 20.05.2019. [10.01.2021. red.].

2 Eiropas Parlamenta un Padomes Direktīva 2019/771 par atsevišḳiem preču pārdošanas līgumu aspektiem, ar kuru groza Regulu (ES) 2017/2394 un Direktīvu 2009/22/EK un atcel Direktīvu 1999/44/EK. Pieņemta 20.05.2019. [10.01.2020. red.].

${ }^{3}$ Eiropas Komisijas 06.05.2015. paziņojums Eiropas Parlamentam, Padomei, Eiropas Ekonomikas un sociālo lietu komitejai un Regionu komitejai "Digitālā vienotā tirgus stratēgija Eiropai” (COM/2015/0192 final), 2.1. punkts. Pieejams: https://eur-lex.europa.eu/legal-content/LV/TXT/?uri=CELEX\%3A52015DC0192

4 Turpat.

5 Samet A. Global ecomerce market report: ecomerce sales trends and growth statstics for 2021. Pieejams: https://www.businessinsider.com/global-ecommerce-2020-report [aplūkots: 15.01.2021.].

6 Samet A. 2021. 
šāda situācija ir Direktīvu kompleksā regulējuma dēḷ. N̦emot vērā, ka Latvijā jau šobrīd notiek attiecīgo normatīvo aktu grozījumu izstrāde, kā arī ņemot vērā to, ka šie grozījumi, kā tas tiks detalizētāk izklāstīts tālāk, nāks ar zināmiem izaicinājumiem Latvijas tiesību sistēmai, šis raksts ir vērsts uz to, lai, pirmkārt, iepazīstinātu ar paredzēto grozījumu saturu un tvērumu, ciktāl tas attiecas uz līgumu objektu, otrkārt, norādītu uz problemātiku, kas radīsies līdz ar grozījumu stāšanos spēkā, treškārt, sniegtu šīs problemātikas iespējamos risinājumus un, ceturtkārt, visbeidzot, veicinātu diskusiju sabiedrībā, kas savukārt veicinātu sagaidāmo grozījumu kvalitāti.

Šis raksts ir tapis Latvijas Zinātnes padomes apstiprinātajā Fundamentālo un lietišķo pētījumu projektā (FLPP), kurā vērā ņemamu palīdzību ir snieguši arī LU Juridiskās fakultātes studenti Salvis Kārklis un Kristaps Silionovs, kuri projektā piedalās pētnieku asistentu statusā.

\section{Direktīvu tvērums}

Lai gan raksta tēma ir "Pirkuma līguma objekta izpratne jauno patērētāju pirkuma direktīvu gaismā”, jau sākotnēji jāteic, ka Direktīvas skars ne tikai pirkuma līgumu, bet arī citus Latvijas tiesību sistēmā esošos līgumus.

Minētais it īpaši attiecas uz Direktīvu 2019/770, kuras apsvērumos norādīts, ka katra dalībvalsts var brīvi noteikt, kurš tiesību sistēmā esošais līgums būs tas, kas tiks ietekmēts ar šo direktīvu. Proti, Direktīvas 2019/770 12. apsvērumā minēts, ka

Šai direktīvai [..] nebūtu jānosaka līgumu par digitālā satura vai digitālā pakalpojuma piegādi juridiskā bùtība, un jautājums par to, vai lìgums par digitālā satura vai digitālā pakalpojuma piegādi ir uzskatāms, piemēram, par pirkuma, pakalpojumu, nomas vai sui generis lìgumu, būtu jāatstāj valstu tiesību aktu kompetencē.

Faktiski Direktīva 2019/770 ar noteiktiem izņēmumiem attiecas uz gandrīz jebkāda veida atlīdzības līgumu par digitāla satura vai digitāla pakalpojuma sniegšanu patērētājiem. Turklāt atlīdzība šādu līgumu izpratnē var būt ne tikai naudas summa vai vērtības digitāls ekvivalents, bet arī personas dati (sk. Direktīvas 2019/770 3. panta 1. punktu).

Savukārt Direktīva 2019/771 attiecas uz šaurāku iespējamo līgumu tvērumu. Proti, tā attiecas uz līgumiem par preču, tostarp preču, kurām ir digitāli elementi, pārdošanu. Abas Direktīvas nav savstarpēji izslēdzošas, bet gan viena otru papildina. Tomēr, pirms detalizētāk pievērsties šo abu Direktīvu analizēšanai, ir nepieciešams noskaidrot jēdzienu 1) "digitāls saturs"; 2) "prece ar digitāliem elementiem" un 3) "digitāls pakalpojums" būtību, jo šie trīs jēdzieni ir nozīmīgi, lai izprastu ar Direktīvām regulētos līguma objektus.

\section{Direktīvā nozīmīgo jēdzienu skaidrojums}

\section{A. Digitāls saturs}

Jēdziens “digitāls saturs" ir būtisks abu Direktīvu izpratnē, jo tas var ietilpt abu Direktīvu objektos. Šì jēdziena skaidrojums jau šobrīd ir ietverts Patērētāju tiesību aizsardzības likuma 1. panta 8. punktā. Atbilstoši tam digitāls saturs ir [..] dati, 
kas radīti un piegādāti digitālā formātā. Lai gan pirmšķietami šādam jēdziena skaidrojumam problēmas radīt nevajadzētu, tomēr, piemērojot šādu skaidrojumu praksēe, ātri vien nākas saskarties ar problēmsituāciju, t. i., to, vai tiešām Eiropas Savienības likumdevējs jēdzienā "digitāls saturs" ir vēlējies iekḷaut jebkurus datus, par vienīgo priekšnosacijumu atzīstot to, ka tiem ir jābūt digitālā formātā. Ja tāda būtu bijusi Eiropas Savienības likumdevēja griba, tad ātri vien nāktos secināt, ka, piemēram, tulkošanas pakalpojumi, kuru darba rezultāts ir sniegts elektroniskā formātā, vai juridiskie pakalpojumi, kuru rezultāts ir elektroniski sagatavots dokuments, vai arī ārsta e-pasta formā sniegtas rekomendācijas ir digitāls saturs, kurš tādējādi ir nodrošināts ar papildu aizsardzību, iepretim tam, ja šādu darbu rezultāti tiktu sniegti rakstveidā.

N̦emot vērā minēto, digitālu saturu precīzāk būtu definēt kā digitālā formā nodotus datus, ja to nodošana vai izstrāde ir noslēgtā līguma galvenais priekšmets. Lai gan, iespējams, nepilnīga, tomēr šāda definīcija daudz precīzāk atklāj jēdziena "digitāls saturs" dabu, tādējādi jēdzienā iekḷaujot, piemēram, programmatūras, audio materiālus, digitālus attēlus u. c., un vienlaikus ārpus ši jēdziena atstājot tos pakalpojumus un preces, kurās tā digitālā satura īpatnībām parasti ir sekundāra nozīme, piemēram, elektroniski sagatavoti dokumenti, finanšu pakalpojumi u. c.

\section{B. Prece ar digitāliem elementiem}

Jēdziens "prece ar digitāliem elementiem" ir būtisks Direktīvas 2019/771 izpratnē, jo tieši šì direktīva regulē tādus līgumus, uz kuriem pamatojoties tiek pārdotas preces ar digitāliem elementiem. Minētais jēdziens līdz šim ir bijis svešs Latvijas tiesību sistēmai. Kā tas izriet no šì brīža plānojamās Patērētāju tiesību aizsardzības likuma grozījumu redakcijas, ${ }^{7}$ arī tur, lai gan bieži pieminēts, tomēr šis jēdziens skaidrots netiek. Jēdziens "prece, kurai ir digitāli elementi", ir pietiekami skaidri atklāts Direktīvas 2019/771 14. un 15. apsvērumā, kuros skaidrots, ka prece ir uzskatāma par tādu, kurai piemìt digitāli elementi, tad, ja

[..] digitālā satura vai digitālā pakalpojuma neesamība neļautu šìm precēm pildìt savas funkcijas vai [..] kad šäds digitāls saturs vai digitāls pakalpojums tiek nodrošināts kopā ar precēm saskaṇā ar šo preču pārdošanas lïgumu.

Jāṇem vērā, ka minētajos direktīvas apsvērumos ir noteiktas arī vairākas prezumpcijas. Atbilstoši tām var noteikt, kad

digitāls saturs vai digitāls pakalpojums tiek nodrošināts kopā ar precēm saskañā ar šo preču pärdošanas lïgumu.

Šajā ziṇā jāṇem vērā gan preču veids, gan jebkāds attiecīgo komersantu (piemēram, pārdevēju, ražotāju, to pilnvarnieku) paziṇojums.

Citiem vārdiem skaidrojot Direktīvas 2019/771 14. un 15. apsvērumā minēto, par preci ar digitāliem elementiem būtu atzīstamas četru veidu preces:

1) prece, kuras funkciju īstenošana ir darìta atkarīga no šai precei nepieciešamā digitālā satura vai digitālā pakalpojuma (Direktīvas 2019/771 14. apsvēruma 1. teikums); vai arī

${ }^{7}$ Likumprojekts “Grozijumi Patērētāju tiesību aizsardzības likumā”. Pieejams: http://tap.mk.gov.lv/ doc/2020_12/EMLik_251120_groz_PTAL.1064.doc [aplūkots: 04.01.2021.]. 
2) prece, attiecībā uz kuru līguma puses ir skaidri vienojušās, ka tā ietvers digitālu saturu vai digitālu pakalpojumu (Direktīvas 2019/771 15. apsvēruma 3. teikums); vai arī

3) prece, kurā pēc tās būtības un veida ir ietverams konkrēts digitāls saturs vai digitāls pakalpojums (Direktīvas 2019/771 15. apsvēruma 4. teikums); vai arī

4) prece, attiecībā uz kuru komersants, lai gan to nav tieši norādījis līgumā, konkrētā digitālā satura vai digitālā pakalpojuma ietveršanu ir ìpaši piesolījis (Direktīvas 2019/771 15. apsvēruma 4. teikums). ${ }^{8}$

Atbilstoši Direktīvas 2019/771 14. un 15. apsvērumā minētajiem četriem preču veidiem, par "preci ar digitāliem elementiem" varētu uzskatīt, piemēram:

1) viedpulksteni, kurš savas funkcijas var pildit tikai tad, ja tas ir nodrošināts ar nepieciešamo digitālo saturu (programmatūru);

2) datoru, kurš atbilstoši noslēgtajam līgumam tiek pārdots jau ar iestatìtu operētājsistēmu;

3) viedtālruni, no kura pat specifisku līguma noteikumu neesamības gadījumā ir logiski sagaidāms, ka tajā būs ietverti noteikti digitāli elementi, piemēram, pulksteņa programma, kas l̦auj tālruṇa lietotājam redzēt un iestatīt datumu un laiku, vai programma, kas l̦auj tālruṇa lietotājam redzēt akumulatora uzlādes līmeni utt.;

4) transportlīdzekli ar navigācijas sistēmu, kuras esību komersants līdz tam bija piesolījis, piemēram, komercgarantijā vai televīzijas reklāmā.

\section{Digitāls pakalpojums}

Atbilstoši Direktīvas 2019/770 2. panta 2. punktam ar jēdzienu "digitāls pakalpojums" saprotami divu kategoriju pakalpojumi:

1) pakalpojums, kas patērētājam dod iespēju sagatavot, apstrādāt vai uzglabāt datus vai piekḷūt tiem digitālā veidā; vai

2) pakalpojums, kas ḷauj kopīgot datus vai jebkādā citā veidā mijiedarboties ar tiem digitālā veidā, ko augšupielādējis vai radījis patērētājs vai citi minētā pakalpojuma lietotāji.

Direktīvas 2019/770 2. panta 2. punktā paredzēta salīdzinoši plaša digitāla pakalpojuma definīcija. Tomēr šo definīciju sašaurina tostarp šīs direktīvas 3. panta 5. punkta a) apakšpunkts, jo atbilstoši tam sniegtais pakalpojums nevar tikt atzìts par digitālu pakalpojumu tikai tādēḷ, ka tā rezultāta radī̌sanas vai tā nodošanas patērētājam nolūkā komersants izmanto digitālus līdzekḷus. Nosakot, vai sniegtais pakalpojums ir digitāls pakalpojums Direktīvu izpratnē, parasti būtu jāvērtē atbilstoši līgumam sniegtā pakalpojuma būtība un mērķis. Piemēram, līgums, kura ietvaros komersants dod iespēju patērētājam izveidot e-pasta adresi un ar šìs adreses starpniecību saṇemt un pārsūtìt e-pasta vēstules un elektroniskus dokumentus citām personām, ir līgums par digitāla pakalpojuma sniegšanu, jo šì pakalpojuma būtība un mērḳis ir dot iespēju patērētājam arī apstrādāt, uzglabāt un koplietot digitālus datus. Savukārt komersanta rīcība,

\footnotetext{
8 Atbilstoši Direktīvas 2019/771 15. apsvērumam šaubu gadījumā (par to, vai digitālais saturs vai digitālais pakalpojums ir iekḷauts preces pārdošanas līgumā) pieṇem, ka ir pārdota prece ar digitāliem elementiem.
} 
elektroniski nosūtot līgumu vai paziṇojumu patērētājam, nav uzskatāma par digitāla pakalpojuma sniegšanu.

Mūsdienās pastāv dažādu veidu digitāli pakalpojumi, tostarp: 1) digitālās televīzijas pakalpojumi; 2) sociālajos plašsaziṇas līdzekḷos piedāvāta video un audio koplietošana, tekstapstrāde vai spēles; 3) mākoṇglabāšanas pakalpojumi; 4) tīmekḷa e-pasta un tiešsaistes ziṇapmaiṇas pakalpojumi utt.

\section{Direktīvas 2019/770 un Direktīvas 2019/771 nošķiršana}

Pēc tam, kad ir gūta izpratne par to, kas ir saprotams ar "digitālu saturu", "digitālu pakalpojumu" un "preci, kurai ir digitāli elementi”, iespējams pievērsties abu šo Direktīvu tvēruma detalizētākai analīzei. Respektīvi, ievērojot, ka Eiropas Savienības likumdevējs šajā jomā ir paredzējis divas atsevišķas direktīvas, personām varētu rasties jautājums - kuras direktīvas tvērumā ietilpst tās noslēgtais līgums? Šāds jautājums var būt svarīgs, jo abas Direktīvas aizliedz nacionālajos likumos paredzēt no Direktīvām atšķirīgus noteikumus, ciktāl Direktīvās nav noteikts citādi. Tādēl tālāk šajā rakstā tiks sniegts vispārīgs skaidrojums, kā šīs Direktīvas savstarpēji nošķirt. Savukārt raksta noslēgumā tiks analizēta katras konkrētās direktīvas ietekme uz pirkuma līguma tiesisko dabu un tā līdzšinējo izpratni Latvijas tiesību sistēmā.

Kā jau minēts iepriekš, Direktīva 2019/770 ar noteiktiem izņēmumiem attiecas gandrīz uz jebkāda veida atlīdzības līgumu par digitāla satura vai digitāla pakalpojuma sniegšanu patērētājam. Savukārt Direktīva 2019/771 attiecas uz līgumiem par preču, tostarp preču, kurām ir digitāli elementi, pārdošanu. Abas šīs Direktīvas nav savstarpēji izslēdzošas, bet gan viena otru papildina.

Nav grūti iztēloties situāciju, ka persona iegādājas jaunāko iPhone viedtālruni ar visām tam raksturīgajām specifikācijām. Ievērojot, ka šim viedtālrunim ir digitāli elementi, piemēram, operētājsistēma, modinātājpulksteṇa programma un fotoaparāta programma, šis līgums būtu uzskatāms par preces, kurai ir digitāli elementi, pārdošanas (pirkuma) līgumu un ietilptu tieši Direktīvas 2019/771 tvērumā.

Savukārt, ja pēc šī viedtālruṇa iegādes patēētājs no lietotṇu veikala nopērk un savā viedtālrunī lejupielādē spēles lietotni, šīs spēles lietotnes iegādes līgums neietilpst paša viedtālruṇa pārdošanas līgumā un spēles lietotnes iegāde būtu Direktīvas 2019/770 darbības jomā.

Minētajam principam ir vairāki uz log̣ikas apsvērumiem balstīti izṇēmumi. Piemēram, Direktīva 2019/771 nav attiecināma uz gadījumiem, ja digitālu saturu piegādā tādos materiālos informācijas nesējos kā DVD, CD, USB zibatmiṇas un atmiņas kartes ar noteikumu, ka šis informācijas nesējs paredzēts vienīgi kā digitālā satura nesējs (sk. Direktīvas 2019/771 3. panta 4. punkta a) apakšpunktu). Piemēram, ja patērētājs veikalā nopērk CD disku ar spēli vai operētājsistēmu Windows 10, tad uz šo līgumu vispārīgi būtu attiecināmi vienīgi Direktīvas 2019/770 noteikumi, jo šis CD disks ir paredzēts vienīgi kā digitālā satura nesējs. Šāda atziņa par to, ka nebūtu nošķirami gadījumi, kad digitāls saturs tiek iegūts lejupielādes ceḷā vai datu nesēja iegādes ceḷā, ir atrodama arī doktrīnā. ${ }^{9}$

${ }^{9}$ Micklitz H. W., Reich N. The Basics of European Consumer Law. Makau, 2007, p. 192. 


\section{Direktīvu ietekme uz pirkuma līguma tiesisko dabu un tā izpratni Latvijas tiesību sistēmā}

Šobrīd līgumus starp patērētāju un saimnieciskās darbības veicēju, kuru objekts ir digitāls saturs vai prece ar digitāliem elementiem, regulē Patērētāju tiesību aizsardzības likums. Atbilstoši Patērētāju tiesību aizsardzības likumam "prece ar digitāliem elementiem" ir ietverta jēdziena "prece" definīcijā, ${ }^{10}$ savukārt digitāls saturs tiek definēts kā "dati, kas radīti un piegādāti digitālā formātā"11.

Lai gan Patērētāju tiesību aizsardzības likumā nav norādīts, atbilstoši kāda veida lígumam patērētājam var tikt nodots digitāls saturs vai prece ar digitāliem elementiem, no šì likuma 1. panta 6. punkta var secināt, ka "prece ar digitāliem elementiem" ir kustama lieta, kas var tikt pārdota patērētājam. Salïdzinoši sarežgìtāk ir klasificēt līgumu, kura objekts ir nevis prece ar digitāliem elementiem, bet gan digitāls saturs. Lai gan Patērētāju tiesību aizsardzības likuma $4 .{ }^{1}$ panta septìtā daļa noteic, ka

Šà likuma noteikumi, kuri regulē pakalpojuma sniegšanu, tiek piemèroti digitālajam saturam, kas netiek piegādāts materiālajā datu nesējā, ja patērētāju tiesību aizsardzību regulējošās speciālajās normās nav noteikts citādi,

tas nenozīmē, ka līgums, kura objekts ir digitāls saturs, ir uzskatāms par pakalpojumu sniegšanas lïgumu.

Kā tas norādīts 2014. gada 24. aprị̣̄a likuma Grozījumi Patērētāju tiesību aizsardzības likumā ${ }^{12}$ likumprojekta anotācijā, šāda veida līgumi nebūtu jāuzskata par preces pirkuma vai pakalpojuma līgumu. Proti, digitāls saturs netiek definēts kā prece vai pakalpojums, bet, lai normatīvā akta lietotājam būtu skaidrs, kādas prasības ir piemērojamas digitālā satura līgumiem, šiem līgumiem piemērojami Patērētāju tiesību aizsardzības likuma noteikumi par pakalpojumiem, ciktāl patēētāju tiesību aizsardzību regulējošos normatīvajos aktos nav noteikts citādi. ${ }^{13}$

Vienlaikus, ievērojot, ka Patērētāju tiesību aizsardzības likums nenoteic, atbilstoši kāda veida līgumam patērētājam var tikt nodotas preces ar digitāliem elementiem un it īpaši digitāls saturs, šo jautājumu nepieciešams izvērtēt no civiltiesību skatpunkta, ievērojot vairākas šādu līgumu objektu ìpatnības. Šajā ziṇā norādāms, ka, pirmkārt, precē ietvertais digitāls saturs vai digitāls pakalpojums nav pakḷauts tādiem pašiem piegādes noteikumiem, kādiem būtu pakḷauta telpiski norobežojama lieta, otrkārt, digitāla satura vai digitāla pakalpojuma atbilstība tam piesolītajām īpašībām var būt atkarīga no paša patēerēāja rīkiem, kādus tas izvēlēejies, lai izmantotu digitālo saturu vai digitālo pakalpojumu (piemēram, patēētājam piederošais dators tā trūkumu dēḷ nav spējīgs atvērt programmatūru, kuru tas iegādājies), treškārt, digitāls saturs vai digitāls pakalpojums, atšḳirīibā no parastas lietas, piemēram, grāmatas, var tikt pakḷauts atjauninājumiem, kas var būt nepieciešami, lai nodrošinātu tā atbilstību solìtajām îpašỉbām solìtajā termiṇā.

10 Patērētāju tiesību aizsardzības likuma 1. panta 6. punkts noteic: "Digitālais saturs kopā ar materiālo datu nesēju (CD, DVD vai līdzīgu materiālo datu nesēju) uzskatāms par preci.”

11 Patērētāju tiesību aizsardzības likuma 1. panta 8. punkts.

12 Ar šiem grozījumiem $4{ }^{1}$ panta septītā daḷa tika ietverta Patērētāju tiesību aizsardzības likumā.

13 24.04.2014. likuma "Grozījumi Patērētāju tiesību aizsardzības likumā” likumprojekta anotācija. Pieejama: http://titania.saeima.lv/LIVS11/SaeimaLIVS11.nsf/WEBRespDocumByNum?OpenView\&restricttocateg ory $=724 /$ Lp11 $\mid 2483$ 
Šobrīd Latvijā jautājumi, tostarp par digitāla satura atjaunināšanu, integrēšanu, saderību (savietojamību), funkcionalitāti un sadarbspēju, ir bez detalizētāka tiesiskā regulējuma, kuru savukārt tad arī ir paredzēts izstrādāt, ieviešot Direktīvas. Ieviešamās izmaiņas būtiski skars arī tiesību un pienākumu sadalījumu līgumā, kurš noslēgts starp patērētāju un saimnieciskās darbības veicēju, ja tā ietvaros ir paredzēts nodot patērētājam digitālu saturu, digitālu pakalpojumu vai preci ar digitāliem elementiem. Ar Direktīvām ieviešamais regulējums rada padzị̣inātu un pilnvērtīgāku izpratni par digitāla satura, digitāla pakalpojuma un preces ar digitāliem elementiem būtību. Tomēr tas joprojām nesniedz atbildi par līgumu, kuru objekts ir digitāls saturs vai digitāls pakalpojums, klasifikāciju, kas var būt nozīmīga, lai noteiktu šādiem līgumiem piemērojamos noteikumus (normatīvos tiesību aktus) tādos aspektos, kurus neregulē Patēerēāju tiesību aizsardzības likums. ${ }^{14}$

Šo līgumu klasifikācijas problemātika ir īpaši nozīmīga gadījumā, ja iepriekš minētie līgumi tiek noslēgti starp personām, uz kurām Patērētāju tiesỉbu aizsardzības likumā ietvertie noteikumi nav attiecināmi (piemēram, lïgumi starp saimnieciskās darbības veicējiem, līgumi starp patērētājiem), jo neviens normatīvais tiesību akts Latvijā ārpus patērētāju tiesību aizsardzības regulējuma šobrīd neparedz specifisku regulējumu šāda veida līgumiem.

\subsection{Direktīvas 2019/770 ietekme uz pirkuma līguma objektu un tā izpratni Latvijas tiesỉbu sistēmā}

Līdz ar Direktīvas 2019/770 ieviešanu (kopsakarā ar jau pastāvošajām īpatnībām Latvijas tiesību sistēmā) no līgumu klasifikācijas viedokḷa ir nepieciešams noškịirt trīs dažādas situācijas:

1) līguma objekts ir digitāls saturs, kuram nav nepieciešami atjauninājumi (piemēram, video materiāli, fotoattēli, skaņdarbi u. c.);

2) līguma objekts ir digitāls saturs, kuram ir nepieciešami atjauninājumi (piemēram, datoru operētājsistēmas, datorspēles, datoru antivīrusi u. c.);

3) līguma objekts ir digitāls saturs, kuru persona saņem, apmainot personai piederošos datus pret šo vēlamo digitālo saturu, citiem vārdiem, digitāls saturs, kuru persona saņem maiņas līguma noslēgšanas rezultātā, kur viens no maiņas objektiem ir šìs personas dati (piemēram, reǵistrācija Facebook vietnē, elektroniska zinātniska raksta saṇemšana, ja tā saṇemšanai ir nepieciešama reg̀istrācija, u. c.).

Kā redzams, tikai pirmajos divos gadījumos ir pamats runāt par ko līdzīgu pirkuma līgumam, bet trešajā gadījumā ir konstatējami maiṇas līguma elementi. Savukārt atšķirīibas starp pirmajiem diviem gadījumiem ir tieši pašā līguma objektā.

\subsubsection{Digitāls saturs kā pirkuma līguma objekts}

Civillikuma 2005. pants noteic, ka par pirkuma lïguma objektu var būt lietas, ko aṭ̣auts un iespējams atsavināt, saprotot ar to ne vien k̦ermeniskas lietas, bet arī lietu un saistību tiesîbas. ${ }^{15}$ Tătad par pirkuma līguma objektu var būt gan

${ }^{14}$ Sk., piem., Patēerēāju tiesību aizsardzības likuma $2 .{ }^{1}$ panta otro daḷu.

${ }^{15}$ Rīgas apgabaltiesas Civillietu tiesas kolēgijas 19.10.2017. spriedums lietā Nr. C33293814, 6. lpp. 
ķermeniskas, gan bezķermeniskas lietas, ciktāl to atsavināšana ir atl̦auta. N̦emot vērā iepriekš minēto, nākas uzdot jautājumu: vai digitālu saturu, kas pēc būtības ir binārais kods, var atzīt par ķermenisku vai par bezķermenisku lietu? Attiecībā uz šo jautājumu - kā digitāls saturs ir klasificējams no lietu tiesību viedokḷa - Latvijā līdz šim juristu starpā nav bijušas diskusijas, kas, iespējams, veicinātu atbildes rašanu.

Digitāls saturs kā atsavinājuma līguma objekts šķiet patiešām problemātisks. Atsavinājuma līgumus vienojošā pazìme ir tā, ka šo līgumu noslēgšanas vai izpildes rezultātā pāriet īpašuma tiesības, kas savukārt nozīmē, ka līguma objektam ir jābūt tādam, pār kuru īpašuma tiesība vispār var tikt īstenota. Kā uz to norāda Civillikuma 927. pants, īpašuma tiesība var tikt īstenota tikai pār lietu (gan ķermenisku, gan arī bezķermenisku). To n̦emot vērā, gadījumā, ja tiktu atzīts, ka digitāls saturs nav lieta, nāktos secināt, ka pār digitālu saturu nevar tikt īstenota īpašuma tiesība, kas savukārt nozīmētu, ka digitāls saturs vispār nevar būt par atsavinājuma līgumu objektu, jo pār to nevar tikt īstenota īpašuma tiesību pāreja.

N̦emot vērā, ka šis jautājums Latvijas tiesību sistēmā nav tālāk analizēts, lietderīgi būtu aplūkot Latvijai radniecīgajās vācu tiesībās paustās atziṇas. Paturot prātā to, ka vācu tiesībās netiek atzīts bezḳermenisku lietu institūts, vācu zinātnieku ieskatā, elektroniski dati nevar tikt atzīti par lietām, jo tiem trūkst fizikālās plaknes un telpiskās norobežotības. ${ }^{16}$ Vienlaikus vācu tiesībās ir atzìts, ka elektroniski dati var tikt atzīti par nemateriālu labumu, kas ir radies domāšanas ceḷā, un tādēl arī tie var tikt aizsargāti no tiesību viedokḷa. ${ }^{17}$ Vācu tiesību sistēmā uz objektiem, kurus nevar atzìt nedz par lietām, nedz par tiesībām, bet kuri var būt par atsavinājuma līguma objektu, tiek attiecināts jēedziens "bezḳermeniski objekti" (vācu val. - Unkörperliches Objekt), ar šo institūtu aptverot izgudrojumus, idejas, domēnu nosaukumus, zinātību u. c. ${ }^{18}$ Direktīvas 2019/770 izpratnē arī digitāls saturs tā fizikālās plaknes trūkuma dēḷ var tikt atzìts par bezķermenisku objektu, kam ir mantiska vērtība un kas tādējādi var būt par līgumu objektu. Šajā ziṇā jānorāda, ka jēguma ziṇā līdzīgs jēdziens ir ietverts Komerclikuma 18. pantā, kurā noteikts, ka

Uzñēmums ir organizatoriski saimnieciska vienība. Uzñēmumā ietilpst komersantam piederošas ķermeniskas un bezķermeniskas lietas, kā arī citi saimnieciski labumi (vērtības) [autora pasvìtrojums], kurus komersants izmanto komercdarbïbas veikšanai.

Šajā gadījumā, līdzīgi kā tas ir Vācijā, ar jēdzienu "citi saimnieciski labumi” tiek aptverti visi tie objekti, kuri gan ir ārpus jēdziena "lieta" tvēruma, bet kuri tomēr var tikt mantiski novērtēti. ${ }^{19}$

Lai gan materiālās īpatnības, kas ir raksturīgas lietām, var piemist arī datu nesējiem, uz kuriem elektroniskie dati atrodas (disketes, diski, cietie diski, zibatmiṇas utt.), tomēr tādēl vien paši dati nekḷūst par lietu. Salīdzinājumam varētu

${ }^{16}$ Schubert C. (Red.), Stresemann C. Münchener Kommentar zum Bürgerlichen Gesetzbuch. Band 1. Allgemeiner Teil. $\$ \$ 1-240$. AllgPersönlR. ProstG. AGG. 8. Auflage. München: C. H. Beck, 2018, $\$ 90$, Rn. 25.

17 Schubert C. (Red.), 2018, \$90, Rn. 25.

${ }_{18}$ Westermann H. P. (Red.), Westermann H. P. Münchener Kommentar zum Bürgerlichen Gesetzbuch. Band 4. Schuldrecht. Besonderer Teil I. $₫ \$ 433-534$. Finanzierungsleasing. CISG. 8. Auflage. München: C. H. Beck, 2019, $\$ 453$, Rn. 6 .

${ }^{19}$ Strupišs A. Komentārs pie Komerclikuma 18. panta, 2019. Pieejams: https://komentari.info/index. php?lv=1\&likums $=4 \&$ komentars $=11$ 
minēt, ka grāmata ir ķermeniska lieta, tomēr tajā ietvertais stāsts nekḷūst par ķermenisku lietu tādẹl vien, ka tas ir iespiests grāmatā.

Apkopojot iepriekšējās rindkopās minēto, ṇemot vērā Latvijas tiesību sistēmas regulējumu, jāatzīst, ka digitāls saturs nevar būt par atsavinājuma līgumu, t. sk. pirkuma līguma, objektu, jo to nevar uzskatīt nedz par k̦ermenisku, nedz par bezķermenisku lietu. Līdzīgas atziņas ir sastopamas arī citās jurisdikcijās (piemēram, Belıgijā, Anglijā un Velsā, Francijā, İrijā, Lietuvā, Luksemburgā, Maltā, Zviedrijā, Slovēnijā, Nīderlandē un Amerikas Savienotajās Valstīs), piemēram, norādot, ka mākoņdatošanas līgumiem (cloud computing contracts - angḷu val.) pēc būtības nevar tikt piemēroti noteikumi, kas regulē preču pārdošanu, jo preces parasti tiek definētas kā materiāli kustami priekšmeti, kas parasti nebūtu attiecināmi uz mākoṇdatošanu. ${ }^{20}$

Pamatojoties uz iepriekš paustajām atziņām, raugoties uz šì brīža regulējumu, nākas atzìt, ka līgumi, kuri kādai personai dod tiesību izmantot digitālo saturu, ir atzīstami nevis par pirkuma līgumiem, bet gan par netipiskiem jeb sui generis līgumiem, kas nebauda detalizētu tiesisko regulējumu, ciktāl šo līgumu saturs nav noteikts ar normatīvajos tiesību aktos pārṇemtajiem Direktīvas 2019/770 noteikumiem.

Tomēr, ņemot vērā līgumu, kuru objekts ir digitāls saturs, arvien pieaugošo popularitāti mūsdienās, autora ieskatā, būtu nepieciešams paplašināt Civillikuma 2002. pantā ietverto pirkuma līguma definīciju, iespējams, piezīmes veidā, norādot, ka pirkuma līguma regulējums, ciktāl tas ir iespējams, piemērojams arī citu objektu iegādei (iespējams, lai modernizētu Civillikuma regulējumu, šāda piezīme būtu iekḷaujama arī citos atsavinājuma līgumos). Šajā ziñā vērts norādīt, ka Vācijā minētais problēmjautājums tiek regulēts līdzīgi. Tā Vācijas Civilkodeksa 453. panta pirmā daḷa noteic, ka Noteikumi par lietu iegādi tiek piemēroti ar nepieciešamajām izmaiṇām tiesību un citu priekšmetu iegādēể. Šāda pieeja atbilst arī tiesību literatūrā paustajām atziṇām, ka līgumiem, ar kuriem tiek nodots digitāls saturs, piemīt kvazipirkuma līguma daba, ${ }^{22}$ un Eiropas Savienības Komisijas 2015. gada 17. decembra darba dokumentā (ietekmes novērtējumā, kas tika izstrādāts pirms Direktīvu ieviešanas) norādìtajai pozīcijai, ka noteikumiem par digitālo saturu pēc iespējas jābūt balstītiem uz preču pārdošanas noteikumiem, un atkāpes būtu pamatotas tikai, lai ņemtu vērā digitālā satura specifiku. ${ }^{23}$ Papildus kā alternativvs risinājums būtu izvērtējama šāda līguma definēšana Patērētāju tiesību aizsardzības likumā, tomēr šāda pieeja būtu vērtējama kā mazāk vēlama, jo tādējādi nebūtu novērsts regulējuma trūkums gadījumā, kad digitāls saturs tiek nodots, piemēram, komersantu starpā.

20 DLA Piper UK LLP. Comparative Study on Cloud Computing Contracts. Final Report. Luxembourg: Publications Office of the European Union, 2015, p. 28. Pieejams: https://op.europa.eu/en/publicationdetail/-/publication/40148ba1-1784-4d1a-bb64-334ac3df22c7

${ }^{21}$ Bürgerliches Gesetzbuch [Vācijas Civillikums]. Pieejams: http://bundesrecht.juris.de/bundesrecht/bgb/ gesamt.pdf [aplūkots 26.01.2021.].

22 Micklitz H. W., Reich N. 2007. p. 192.

${ }^{23}$ Sk.: European Union Commission Staff Working Document. Impact Assessment. Accompanying the document - Proposals for Directives of the European Parliament and of the Council (1) on certain aspects concerning contracts for the supply of digital content and (2) on certain aspects concerning contracts for the online and other distance sales of goods (SWD/2015/0274 final/2 - 2015/0287 (COD)). Brussels, 17 December 2015, point 1.1. Pieejams: https://eur-lex.europa.eu/legal-content/EN/TXT/? qid=1450432347519\&uri=SWD:2015:274:REV1 


\subsubsection{Atjauninājumiem pakḷauts digitāls saturs}

Tiesiskā situācija no līgumu klasifikācijas viedokḷa kḷūst vēl sarežgî̀tāka, kad digitāls saturs ir pakḷauts atjauninājumiem, piemēram, operētājsistēmas, antivīrusi, datorspēles u. c. Gadijumā, ja patērētājs iegādājas digitālo saturu, kurš var tikt mainīts (atjaunināts), lai nodrošinātu digitāla satura atbilstību vismaz garantijas periodā, vai arī tas šajā periodā var tikt uzlabots, patērētājam līdz ar līguma objekta iegūšanu savā varā rodas arī prasījuma tiesība - tiesība prasīt atjauninājumus.

Pieņemot, ka nākotnē atsavinājuma līgumu regulējums varētu tikt attiecināts arī uz digitālu saturu, no līgumu klasifikācijas viedokḷa šajā gadījumā būtu apskatāmi divi iespējamie risinājumi: 1) digitāla satura pirkuma līgumu, kas ietver tiesību prasìt atjauninājumus, varētu uzskatīt par vienu no pirkuma līguma blakus līgumiem; 2) šāds līgums varētu būt atzīstams par jauktu līgumu, kas ietver pirkuma līguma un uzñēmuma līguma elementus.

Attiecībā uz pirmo no piedāvātajiem risinājumiem - analizējamā līguma atzišanu par vienu no pirkuma līguma blakus līgumiem - sākotnēji jānorāda, ka Civillikuma Saistîbu tiesību daḷas Trīspadsmitajā nodaḷā ietvertais pirkuma lìguma blakus līgumu (pirkuma līguma paveidu) uzskaitījums nav izsmeḷošs. Šāda norāde ir atrodama Civillikuma 2072. pantā, kurš noteic, ka

lìdzēji bez tam var noslēgt visādus citādus blakus līgumus, ar ko tie pārgroza liguma noteikumus [..].

To ņemot vērā, varētu uzskatīt, ka digitāla satura pirkuma līgums, kura objekts ir pakḷauts atjauninājumiem, varētu tikt atzīts kā viens no pirkuma līguma veidiem, kurā papildus tiek noslēgts akcesors līgums daḷā par atjauninājumu nodrošināšanu. Vispārīgi blakus līgumu jeb akcesoru līgumu noslēgšanas gadijumā vienlaikus ar galveno saistību tiek radīta vēl viena, pakārtota saistība, kuras pastāvēšana ir atkarīga no galvenās saistības pastāvēšanas. Proti, patērētājs, noslēdzot pirkuma līgumu, kura objekts var tikt paḳ̣auts atjauninājumiem, vienlaikus rada trīs saistības - divas saistības, kas izriet no pirkuma līguma, kurās komersants apṇemas nodot digitālo saturu, bet patēētājs apṇemas veikt samaksu, un trešo saistību - saskaṇā ar to komersantam ir pienākums veikt digitāla satura atjaunināšanu, bet patērētājam ir tiesības šādus atjauninājumus pieprasīt. Šāda pieeja prima facie šḳiet korektāka, īpaši ņemot vērā, ka atjauninājumu nodrošināšanas pienākums var rasties, tikai esot spēkā (galvenajam) līgumam par digitāla satura nodošanu, un tādējādi to varētu uzskatīt par ìpašu pirkuma līguma paveidu.

Attiecībā uz otro risinājumu - analizējamā līguma atzīšanu par jauktu līgumu - sākotnēji jāatgādina, kas ir jaukts līgums. Jaukts līgums ir līgums, kas sastāv no vairākiem tipisku un netipisku līgumu elementiem, kurus nav iespējams "saskaldīt" nošķiramos līgumos. ${ }^{24}$ Atzīstot, ka līgums, kas tiek noslēgts starp patērētāju un komersantu, kura ietvaros tiek atsavināts atjauninājumiem pakḷauts objekts, ir jaukts līgums, šādu līgumu veidotu pirkuma līguma un uzṇēmuma līguma elementi. Šādā jauktā līgumā pirkuma līguma elementi būtu saskatāmi lìdz digitālā satura saņemšanas brīdim, turpretī tālākās tiesiskās attiecības, t. i., pienākumu veikt atjauninājumus, regulētu uzṇēmuma līguma elementi. Šo līgumu nošķ̧iršana pilnībā nav iespējama tādẹl, ka klasisks pirkuma līgums nav

24 Balodis K. Ievads Civiltiesībās. Rīga: Zvaigzne ABC, 2007, 184. lpp. 
savienojams ar atjauninājumu institūtu, savukārt uzṇēmuma līgums atbilstoši Civillikuma 2223. panta otrajai daḷai ietver pienākumu maksāt par paveikto darbu, tiklīdz pasūtītājs (patērētājs) atzīst to par labu esam. Pieṇemot, ka atsevišķa samaksa par atjauninājumiem nav paredzēta, faktiski uzṇēmuma līgums kḷùtu par bezatlīdzības līgumu, kas savukārt nav iespējams. Turklāt uzṇēmuma līguma gadījumā atbilstoši Civillikuma 2212. pantam tiek izgatavots pasūtītāja lūgts pasūtỉjums, turpretī atjauninājumu saturs praksē gandrīz nekad nav atkarīgs no patērētāju vēlmēm. Vienlaikus gan atjauninājumu gadījumā ir saskatāms uzṇēmuma līgums pēc būtības, jo komersants uzṇemas uzlabot konkrētu objektu - digitālu saturu, kas pieder patērētājam.

Šādā gadījumā tiesiskie strīdi, ja tādi radīsies, būs regulējami pēc tā likumā ietvertā regulējuma noteikumiem, par kādiem puses būs vienojušās, savukārt, ja šādas vienošanās nav, var tikt izmantota kombinējošā vai absorbējošā metode. Kā to skaidrojis prof. K. Balodis,

izmantojot kombinējošo metodi, atšķirīgo lìgumu pazìmēm atbilstošās līguma sastāvdal̆as tiek nosacìti nošksirtas viena no otras un attiecībā uz katru no tām tiek piemērotas konkrēto līguma tipu regulējošās likuma normas, bet absorbcijas metode nozìmē to, ka jauktajam vai saliktajam lìgumam tiek piemēroti vienu līguma tipu reglamentējošie likuma noteikumi atkarībā no tā, kāda līguma pazìmes jauktajā vai saliktajā lìgumā dominēen ${ }^{25}$

Šāda pieeja, ka noslēgtais līgums būtu atzīstams par jauktu līgumu, l̦autu trāpīgāk piemērot attiecināmo regulējumu. Ir iedomājams liels daudzums digitālā satura, kurā atjauninājumu nozīme būs īpaši augsta. Tā, piemēram, datorspēles, kuras ir iegādājamas jau to sākotnējā versijā, datoru operētājsistēmas, antivīrusi u. c. ir ìpaši pakḷauti atjauninājumiem, tas nozìmè, ka uzṇēmuma līguma elementi šādos gadījumos būtu īpaši nozīmīgi.

Aplūkojot abus iespējamos risinājumus no līgumu klasifikācijas viedokḷa, secināms, ka digitāla satura pirkuma līgumu, kas ietver tiesību prasīt atjauninājumus, pareizāk būtu uzskatīt par vienu no pirkuma līguma blakus līgumiem, jo šāda pieeja atspoguḷo to, ka tieši digitālais saturs kā tāds parasti ir šì līguma galvenais objekts, savukārt atjauninājumi vispārīgi kalpo mērķim nodrošināt digitālā satura atbilstību noteiktā termiṇā. Turklāt saistības nodrošināt atjauninājumus esamība ir atkarīga no galvenās saistības pastāvēšanas. Proti, ja personai atkrīt pienākums nodot pircējam digitālu saturu vai nodrošināt tā atbilstību, pircējs vienlaikus zaudē tiesības prasīt arī digitālā satura atjauninājumus. Papildus norādāms, ka gadījumā, ja šis līgums būtu uzskatāms nevis par vienu no pirkuma līguma blakus līgumiem, bet gan par jauktu līgumu, tas praksē varētu radìt problēmas attiecībā uz komersantam un patērētājam pieejamiem civiltiesiskiem aizsardzības līdzekliem, kas pirkuma līgumam un uzṇēmuma līgumam atsevišķos gadījumos ir savstarpēji pretrunīgi. Piemēram, Civillikuma 2042. pantā ir paredzēta pārdevēja un pircēja iespēja prasīt līguma atcelšanu pārmērīga zaudējuma dēḷ. Savukārt uzṇēmuma līguma gadījumā šādas tiesības pusēm nav paredzētas. Tāpat ir atrodamas būtiskas atšķirības, kas skar līguma izbeigšanas kārtību, izṇēmumiem no līguma saistošā spēka u. tml.

25 Balodis K. 2007, 185. lpp. 


\subsubsection{Digitāls saturs, kas netiek aizsargāts ar Direktīvu 2019/770}

Kā tas tika norādīts iepriekš, Latvijā sniegtā digitālā satura definīcija ir pārāk plaša un aptver arī tādas preces, kuras Eiropas Savienības likumdevējs ir tieši vēlējies izslēgt no papildu aizsardzības sfēras. Tā, piemēram, Direktīvas 2019/770 27. apsvērums noteic, ka šo direktīvu

[..] nevajadzètu piemērot situācijās, kad galvenais līguma priekšmets ir profesionālu pakalpojumu sniegšana [..], Direktīvas 2019/770 29. apsvērums tālāk noteic, ka šì direktīva nebūtu jāpiemēro veselības aprūpei, [..] "Veselības aprūpes” izslēgšana no šìs direktīvas darbības jomas bütu jāattiecina arī uz jebkādu digitālo saturu vai digitālo pakalpojumu.

Arī turpmākajos Direktīvas 2019/770 apsvērumos var atrast jomas, kuras Eiropas Savienības likumdevējs ir vēlējies atstāt bez šajā direktīvā paredzētās aizsardzības, tā norādot, ka šì direktīva nebūtu jāpiemēro pirkuma līgumos, kuru ietvaros tiek iegādāts digitāls saturs, kas ir saistìts ar finanšu sektoru (Direktīvas 2019/770 30. apsvērums), kā arī tā nebūtu jāpiemēro digitālajam saturam, ko sniedz plašai sabiedrībai kā māksliniecisku izpildījumu vai cita veida pasākumu (Direktīvas 2019/770 31. apsvērums). Papildus Direktīvā 2019/770 ir konstatējami arī citi gadījumi, kad papildu aizsardzību patērētājam baudīt nevajadzētu.

Iemesli tam, kādēḷ konkrētās jomas ir ārpus Direktīvas 2019/770 tvēruma, ir dažādi. Attiecībā uz finanšu pakalpojumiem Eiropas Savienības likumdevējs ir norādījis uz to, ka patērētājs pietiekamu aizsardzību saṇem no citiem Eiropas Savienības tiesību aktiem, tādēl vēl lielāka aizsardzība nav nepieciešama (Direktīvas 2019/770 23. apsvērums). Citos gadijumos tiek norādīts, ka tas, ka prece tiek saṇemta kā digitāls saturs, ir maznozīmīgi, jo galvenais, ko patērētājs vēlas saṇemt, pēc būtības ir profesionāls pakalpojums vai profesionāḷa izstrādāts objekts (Direktīvas 2019/770 27. apsvērums). Šāda pieeja lielā mērā pārklājas ar iepriekš šajā rakstā izvirzīto digitāla satura definīciju, kas ir balstīta uz funkcionālu šì jēdziena izpratni. N̦emot vērā Eiropas Savienības likumdevēja skaidrojumus par to, kādēl konkrētie objekti ir ārpus Direktīvas 2019/770 aizsardzības, jāsecina, ka arī pats Eiropas Savienības likumdevējs ir spriedis par labu šai pieejai.

Svarīgi norādīt, ka, neskatoties uz Direktīvā 2019/770 paredzētajiem izṇēmumiem, Latvijā plānotie grozījumi esošajā redakcijā neparedz, ka kāda joma varētu būt ārpus regulējuma tvēruma. Tādējādi veidojas situācija, kurā nacionālais likumdevējs ir paplašinājis to gadijumu loku, kad digitālam saturam paredzētā papildu aizsardzība būtu piemērojama. Minētais savukārt praksē varētu radīt nevēlamas situācijas, kad nacionālais likums pārņemtos direktīvas noteikumus attiecina uz jomām, kuras pamatoti ir ārpus tās tvēruma. Minēto trūkumu būtu lietderīgi novērst līdz brīdim, kad tiks pieņemti grozījumi, tādējādi nodrošinot tiesisko noteiktību un vienveidīgas tiesu prakses piemērošanu.

\subsection{Direktīvas 2019/771 ietekme uz pirkuma līguma objektu un tā izpratni Latvijas tiesību sistēmā}

Atšḳirībā no Direktīvas 2019/770, kuras tvērumā līguma objekts ir digitāls saturs kā nemateriāls objekts ar mantisku vērtību, kas vienmēr sastāvēs no binārā koda (nullēm un vieniem), Direktīvā 2019/771 līguma objekts ir pati prece kā kustama lieta, tai skaitā arī, pamatojoties uz patērētāja specifikācijām, vēl ražojama vai 
izgatavojama lieta (sk. Direktīvas 2019/771 3. panta 2. punktu). Direktīva 2019/771 attiecas uz plašu preču loku, un viens no tās tvērumā ietilpstošajiem objektiem ir "prece, kurai ir digitāli elementi".

Lai gan "prece, kurai ir digitāli elementi”, var ietvert divus atš̌ķirīgus digitālo elementu veidus: 1) digitālu saturu un/vai 2) digitālu pakalpojumu, ar Direktīvu 2019/771 tiek aizsargāta pati prece, savukārt tajā ietvertajam digitālajam elementam attiecībā uz līguma objektu ir sekundāra nozīme. Piemēram, ja patērētājs vēlas veikalā iegādāties digitālo fotoaparātu, viņam nav jāvienojas ar pārdevēju par digitālā elementa - fotoaparāta programmas - pirkumu, bet gan par paša fotoaparāta pirkumu. Pat specifisku līguma noteikumu neesamības gadījumā patērētājs var pamatoti sagaidīt, ka šis fotoaparāts ietvers gan fotoaparāta programmu, ar kuru iespējams uzṇemt fotoattēlus, gan galerijas programmu, ar kuru iespējams aplūkot uzṇemtos attēlus, gan programmu, kas l̦auj lietotājam redzēt akumulatora uzlādes līmeni vai vismaz zināt, kad akumulatoram ir nepieciešama uzlāde, utt. Savukārt, ja šis fotoaparāts neietvers iepriekš minētos digitālos elementus, tad būtu piemērojami noteikumi par preces neatbilstību tās objektīvajām atbilstības prasībām. Respektīvi, Direktīvā 2019/771 līguma objekts un līguma veids vispārìgi nav atkarīgs no precē ietvertā digitālā elementa.

Vienlaikus Direktīvas 2019/771 kontekstā ir nepieciešams savstarpēji nošķirt divus dažādus preces ar digitāliem elementiem pārdošanas veidus atkarībā no atsavinājuma līguma objekta:

1) prece, kurā ietvertajam digitālajam elementam nav nepieciešami atjauninājumi (piemēram, vispārīgos gadījumos mp3 mūzikas atskan,ošanas ierīce);

2) prece, kurā ietvertajam digitālajam elementam ir nepieciešami atjauninājumi (piemēram, viedtālrunis ar iestatītu operētājsistēmu; automašīna ar navigācijas sistēmu).

Gadījumā, ja pircējam nav tiesību prasīt atjauninājumus precē ietvertajam digitālajam elementam, noslēgtais līgums būtu ķermeniskas (kustamas) lietas pirkuma līgums. Šajā ziṇā papildus norādāms, ka līgumu atbilstoši Direktīvas 2019/771 3. panta 2. punktam var noslēgt ari par preci ar digitāliem elementiem, kura vēl nav saražota (pretēji Civillikuma 2007. pantā noteiktajam). Savukārt, ja pircējam ir tiesības prasīt atjauninājumus, tad to, visticamāk, varētu uzskatìt par vienu no pirkuma līguma blakus līgumiem vai arī jauktu līgumu, kas ietver pirkuma līguma un uzṇēmuma līguma elementus. Analizējot abus variantus, par pamatotāku uzskatāms viedoklis, ka gadījumos, kad pircējam ir tiesības prasìt atjauninājumus precē ietvertajam digitālajam elementam, šādu līgumu pareizāk būtu atzìt par vienu no pirkuma līguma blakus lìgumiem, pamatojoties uz jau iepriekš sniegtajiem argumentiem.

\subsubsection{Preces, kas netiek aizsargātas ar Direktīivu 2019/771}

Direktīva 2019/771 neparedz plašu uzskaitijumu ar precēm, kas neietilpst tās tvērumā. Neskatoties uz minēto, gan Patērētāju tiesību aizsardzības likumā esošā, gan grozījumos plānotā "preces" definīcija ir neprecīza, jo tā:

1) bez izṇēmumiem paredz, ka digitāls saturs kopā ar materiālo datu nesēju (CD, DVD vai līdzīgu materiālo datu nesēju) uzskatāms par preci (sk., piem., Patērētāju tiesību aizsardzības likuma 1. panta 6. punktu); 
2) lai gan paredz, ka "preces" jēdzienā ietilpst digitālais saturs kopā ar materiālo datu nesēju, tomēr neparedz, ka "preces" jēdzienā ietilpst digitālais pakalpojums (pakalpojumi) kopā ar materiālo datu nesēju.

Šajā zin̄ā, pirmkārt, norādāms, ka atbilstoši Direktīvas 2019/771 3. panta 4. punkta a) apakšpunktam Eiropas Savienības likumdevējs "preces" jēdzienā nav vēêjies ietvert digitālu saturu kopā ar materiālo datu nesēju, ja materiālo datu nesēju izmanto tikai kā digitālā satura nesēju. No dzīvē gūtajiem novērojumiem ir secināms, ka materiālie datu nesēji nereti kalpo vienīgi kā digitālā satura nesēji. Uz minētajiem materiālajiem datu nesējiem ir attiecināma Direktīva 770/2019 (izṇemot tās 5. un 13. pantu; sk. Direktīvas 770/2019 3. panta 3. punktu), kurā ietvertie noteikumi neattiecas uz precēm. Tādēl, lai nodrošinātu tiesisku noteiktību, Latvijas likumdevējam ir ieteicams precizēt "preces" jēdzienu, neietverot tajā materiālos datu nesējus, ja tos izmanto tikai kā digitālā satura nesējus.

Vienlaikus šādi datu nesēji ir uzskatāmi par precēm Eiropas Parlamenta un Padomes 2011. gada 25. oktobra Direktīvas 2011/83/ES par patērētāju tiesībām izpratnē (sk. Direktīvas 2011/83/ES 19. apsvērumu), un uz tiem ir attiecināmi Direktīvā 2011/83/ES ietvertie noteikumi. Tādējādi likumdevējam uz materiālajiem datu nesējiem, kurus izmanto tikai kā digitāla satura vai digitāla pakalpojuma nesējus (pat ja tie netiek ietverti jēdziena "prece" definīcijā), būtu jāturpina attiecināt no Direktīvas 2011/83/ES transponētos noteikumus (piemēram, nosakot to Patērētāju tiesību aizsardzības likuma $4 .{ }^{1}$ pantā). Alternatīvi likumdevējs varētu neietvert šādus materiālos datu nesējus jēdziena "prece" definīcijā. Tomēr šādā gadỉjumā likumdevējam, lai nodrošinātu atbilstību Direktīvām 770/2019 un 771/2019, būtu jāparedz (piemēram, ietverot attiecīgus grozījumus Patērētāju tiesību aizsardzības likuma $4 .{ }^{1}$ pantā), ka uz minētajiem datu nesējiem nav piemērojami no Direktīvas 771/2019 pārnememtie noteikumi, bet gan ir piemērojami no Direktīvas 770/2019 pārṇemtie noteikumi (iznemot tās 5. un 13. pantu).

Otrkārt, atbilstoši Direktīvas 2019/771 2. panta 5. punkta b) apakšpunktam jēdzienā "preces" ietilpst ne tikai preces, kurās ietverts digitāls saturs, bet arī preces, kurās ietverts digitāls pakalpojums (pakalpojumi). Attiecīgi Latvijas likumdevējam ir jāprecizē "preces" jēdziens, vienveidīgi attiecinot to arī uz tādām precēm, kurās ietverts digitāls pakalpojums.

\section{Direktīvu mijiedarbība ar intelektuālā īpašuma regulējumu}

Nobeigumā jāatzīmē, ka šajā rakstā nav sniegta detalizēta analīze par to, kāda varētu būt mijiedarbība starp Direktīvu jaunieviešamo regulējumu un intelektuālā īpašuma aizsardzības regulējumu Latvijā. Doktrīnā gan tiek pausti viedokḷi, ka Eiropas Savienībā ir novērojama pakāpeniska novirzī̌sanās no licences līguma piemērošanas modela gadījumos, kad līguma objekts ir digitāls saturs. ${ }^{26}$ Tomēr šobrīd Direktīvas neskar esošos Eiropas Savienības un valstu nacionālos tiesỉbu aktus par autortiesībām un blakustiesībām. Attiecīgi gadījumā, ja patērētājs iegādājas digitālu saturu, digitālu pakalpojumu vai preci ar digitāliem elementiem, ir piemērojami Latvijas Republikā spēkā esošie tiesību akti, kas aizsargā intelektuālā īpašuma tiesības (piemēram, Autortiesību likumāā ${ }^{27}$ paredzētie noteikumi par autora

\footnotetext{
${ }^{26}$ Micklitz H. W. 2007, p. 193.

27 Autortiesību likums. Latvijas Vēstnesis, 27.04.2000., Nr. 148/150.
} 
mantiskajām un nemantiskajām tiesībām, licencēšanu, licences līgumiem utt.). Tā jau šobrīd var norādìt, ka programmatūras iegādāšanās nebūt nenozīmē, ka šì persona var rīkoties ar digitālo saturu kā savu. Tomēr pilnvērtīgai minētās mijiedarbības analīzei ir nepieciešams detalizētāks pētījums, kas, iespējams, varētu tikt veikts un atspoguḷots kādā citā rakstā.

\section{Kopsavilkums}

1. Ar Direktīvām ieviešamās izmaiṇas kopumā harmonizēs Eiropas Savienības dalībvalstu starpā pastāvošās dažādỉbas, kas savukārt tādējādi veicinās kopējā tirgus izaugsmi.

2. Izstrādājot grozījumus, ar kuriem plānots ieviest Direktīvu regulējumu, Latvijas likumdevējam vajadzētu apsvērt to, vai šobrīd esošais digitāla satura definējums nav pārāk plašs, tādējādi aptverot arī tādus objektus, kurus acīmredzami nav bijis plānots pakḷaut Direktīvu aizsardzībai.

3. Starp komersantu un patērētāju noslēgtais līgums ir klasificējams dažādi atkarībā no tā, kāds ir līguma objekts. Tāpēc būtu jānošķir gadījumi, kad digitālam saturam vai precei ar digitāliem elementiem nav nepieciešami atjauninājumi; digitālam saturam vai precei ar digitāliem elementiem ir nepieciešami atjauninājumi; digitāls saturs ir iegūts apmaiṇā pret patēētāja datiem.

4. No līgumu klasifikācijas viedokḷa ir savstarpēji jānošķir arī digitāls saturs un prece ar digitāliem elementiem. Digitāls saturs kā līguma objekts var tikt uzskatīts par nemateriālu objektu ar mantisku vērtību, kas vienmēr sastāvēs no binārā koda (nullēm un vieniem), kuru persona iegūst savā varā. Tomēr, atškşirībā no preces ar digitāliem elementiem, šì brīža tiesiskā regulējuma dēḷ digitāls saturs vispār nevar būt par atsavinājuma līguma objektu, jo pār digitālu saturu nevar tikt īstenotas īpašuma tiesības.

5. N̦emot vērā īpatnības, kas rodas līdz ar digitāla satura institūta atzīšanu Latvijas tiesību sistēmā, būtu nepieciešams izstrādāt grozījumus Civillikumā, kas padarìtu šādu institūtu saderīgu ar Latvijas civiltiesībām.

6. Gadijjumos, kad līguma objekts ir digitāls saturs, kuram var būt nepieciešami atjauninājumi, šāds līgums var tikt klasificēts gan kā pirkuma paveids (pirkuma blakus līgums), gan arī kā jaukts līgums.

7. Latvijas likumdevējam vajadzētu rūpīgāk izvērtēt, vai plānotajos grozījumos nebūtu jāietver norāde uz to, kādos gadījumos papildu aizsardzība nebūtu jāpiemēro, par pamatu ņemot Direktīvu noteikumus un tajās norādītos apsvērumus.

8. Direktīvas 2019/771 kontekstā noslēgtais līgums vispārīgi ir uzskatāms par kustamas ķermeniskas lietas (preces) pirkuma līgumu, savukārt precē ietvertajam digitālajam elementam attiecībā uz līguma objektu ir sekundāra nozìme. No civiltiesību viedokḷa šāda līguma klasifikācija ir atkarīga no pircēja tiesībām prasìt atjauninājumus precē ietvertajiem digitālajiem elementiem. Gadījumā, ja pircējam nav tiesību prasīt šāda veida atjauninājumus, noslēgtais līgums būtu kermeniskas (kustamas) lietas pirkuma līgums (Direktiva 2019/771 vienlaikus piẹ̦auj noslēgt arī pirkuma līgumu par vēl nepastāvošu lietu pretēji Civillikuma 2007. pantā noteiktajam). Savukārt gadījumā, ja pircējam ir tiesības prasīt atjauninājumus precē ietvertajiem digitālajiem elementiem, tad šādu līgumu, visticamāk, varētu atzìt par vienu no pirkuma līguma blakus lìgumiem. 
9. Gan Patēētāju tiesību aizsardzības likumā esošā, gan grozījumos plānotā "preces" definīcija ir neprecīza. Latvijas likumdevējam ir ieteicams precizēt "preces" jēdzienu, neietverot tajā materiālos nesējus, ja tos izmanto tikai kā digitālā satura nesējus, kā arī vienveidīgi attiecinot "preces" jēdzienu uz precēm, kurās ietverts digitāls saturs, un uz precēm, kurās ietverts digitāls pakalpojums (pakalpojumi). Alternatīvi likumdevējs varētu neietvert minētos datu nesējus jēdziena "prece" definīcijā, bet gan atsevišksi noteikt, ka uz šiem datu nesējiem nav piemērojami no Direktīvas 771/2019 pārṇemtie noteikumi, bet gan ir piemērojami no Direktīvas 770/2019 pārṇemtie noteikumi (izṇemot tās 5. un 13. pantu), tādējādi nodrošinot atbilstību Direktīvām 770/2019 un 771/2019 bez šādu grozỉjumu ietveršanas jēdziena "prece" definīcijā.

Pētijumu atbalsta Latvijas Zinātnes padomes (LZP) Fundamentālo un lietiškso pētījumu projekts (FLPP) "Patērētāju aizsardzības stiprināšana digitālajā un datu laikmetā: jauno patērētāja pirkuma direktīvu ieviešana Latvijas tiesību

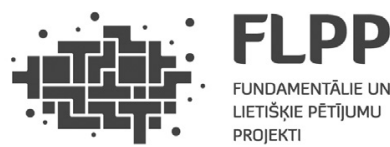
sistēmā". 